\title{
労働条件と高血圧との関倸に関する研究 (警視庁勤務警察官に就いての研究)
}

東京警察病院内科（院長：塩㳄総一博士）(医長：大鉿弘交博士）

市橋 万知子

RELATIONSHIP OF LABOR AND HYPERTENSION. (A Study on Tokyo Metropolitan Police Dept. Officers.)

\section{BY}

Machiko Ichihashi, M.D.

Internal Medicine of Tokyo Metropolitan Police Hospital

(Director: S. Shiozawa, M.D., Chief of Staff: H. Osuzu, M.D.)

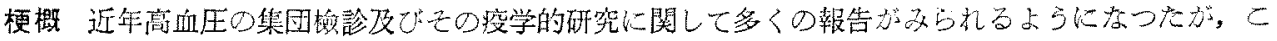

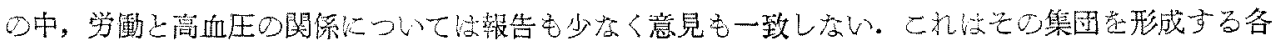

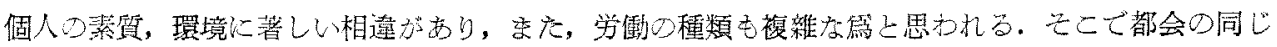

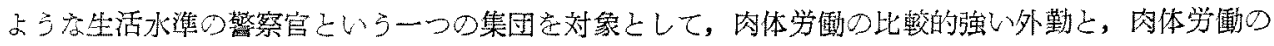

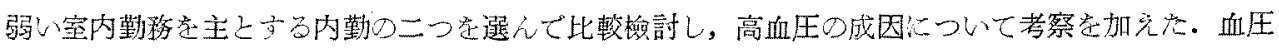

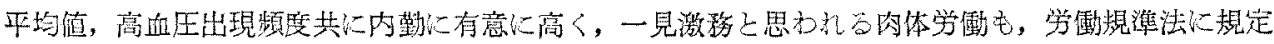

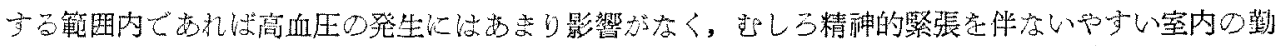

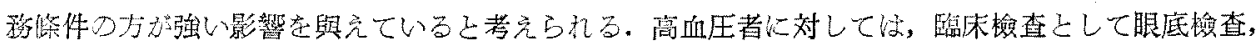

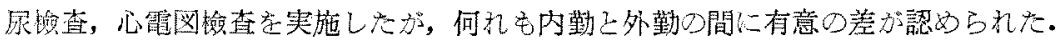

\section{I 緒言}

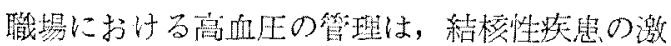
減した現在に扔いて主要かつ緊急の開題であつ

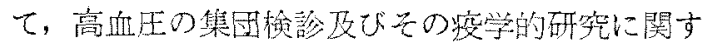
る報告は，国の内外を閏わず必ずしも少存いとは

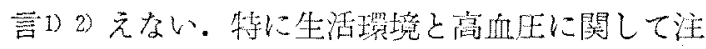

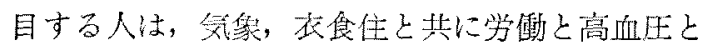

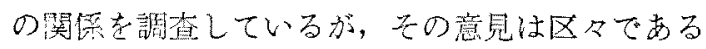
3) 7)。乙れは集団を形成する各㑑人の素買，環境

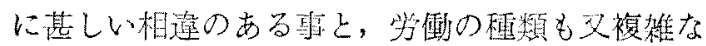
為であるうと思利れる。

㢣察官はその採用時に比較的灌重な身体检查を 通過し，一定期間健愿状態老稩祭された後に，そ

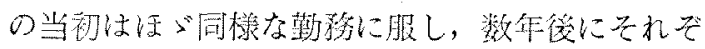

れ専門的な学務に移る人の集団であつて，その勤 務は重筋労働は少ないが, 常住精神的繁張の状態 にあり，時に生命を賭して急険に飛込まざるを得 ないような職業である。従つて健康管理上一般の 肉体または精神勤労者とは暴なつた注意を要する と共に,この集団の労務と高血圧との関係研究 するこ之は，一般高血圧の成因研究に笴与するも のがあるうと老えられる。

著者は警視㕂健康管理堂を中心とした鳘視庁職 員の集団㛟䛦及びそれによつて発見された离血压 症に対して，束京敕察病院において実施した精密 診断の資料によつて，㦄応義熟大学医学部原島進 教授の公臮衛生学的卸指導を得て，警察官の労務

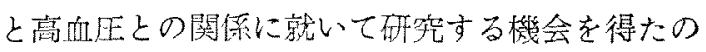


で報告する。

\section{II 研究方法}

1）警視庁職員の中，泗40才以上の者約 6,000 人に，昭和31年より每年 1 回循環器系集団検診を 実施しているが，学衝条件，生活環境条件を出来 るだけ自然のま〉に観察する為，それ迄この檑の 健康管理を全く行なつていなかつた昭和31年度の 第 1 回集団検診の資料の中から，満40寸以上满59 寸迄の男子警察官 5,534人を選んだ。満60才以上 は人数が極放て少ないので除外した。

2）作業別比較の為に前記 5,534人の中から中 等学㗢者の中，肉体労㗢の比較的澈しい外勤（交 番勤務，パトロール，交通整理） 1,728名と，軽 労㗢者の中, 室内で各種の重務的作業に従事する 者（事務，防犯少年係，交通事務，鑑識係，管理 者としての署長，部長，課長等)，2,158名選ん だ.重筋労働者は少数の為, 比較の対象にならな いので除外した、以後前者を外勤, 後者を内勤と 記す。

3）循環器系集団㮩診の結果, 縮期圧 $160 \mathrm{~mm}$ 以上，弛期圧 $100 \mathrm{~mm} H \mathrm{~g}$ 以上の者を東京警察病院に 来院させて臨床検查を実施した。

4）集団梌診時の血圧測定は, Riva Rocci 水 銀血圧計を用い約 5 分以上坐位安静の後右上腕で 測定し，スワン氏第 1 点と第 5 点をそれそれ縮期 圧，弛期圧とした。この検診期間は昭和 31 年 6 月 加 9 月迄.

5）臨床検查としては，既往歷，芜族歷，自党 症状を問診の後，Riva Rocci水銀血圧計を用い 硂位で血圧を測定し，これに理学的検查，心電図 検查，眼底検查，尿検查を加えた。この検查期間 沼和31年 9 月加ら12月迄。

6）血圧严均值及び高血生出現頻度の算出の年 令訂正は，警察官全員の年令分布を基準にした 方，てれは 40〜 44 才 3,078名，45〜49才 1,726 名，50〜54才 551名，55〜59才 179名であつた。 高血纴者の臨床検查の場合の年令訂正は，来院し て検查を受けた全員の年令分布を基準にしたが， それ注40４4才 213名，45～49才 249名，50－54
才 125名，55〜59才45名であつた。

\section{III 検查成績}

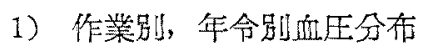

表 1，2，図1は作業別，年令別にみた血圧分 布を\%で示したものである。

縮期圧に就いてみると，外勤，内勤共に分布の 型注汪ぐ正規分布に近い型を示しているが，年令 が進むに従つて耐者共高血压側にずれた型とな り，50才を過ざるとこの傾向は増乃著明となり， 老年型の広い正規分布一と移行している8).外勤

表 1. 男子警察官（40 59才）。作業別年令別血圧 分布\% (縮期圧)

\begin{tabular}{|c|c|c|c|c|c|c|c|c|}
\hline \multirow{3}{*}{${ }_{(m+1)}$} & \multicolumn{2}{|c|}{$40-44$} & \multicolumn{2}{|c|}{$4 B \sim 49$} & \multicolumn{2}{|c|}{$50-54$} & \multicolumn{2}{|c|}{$55-50$} \\
\hline & 办妏 & 内别 & 外 & 肉勤 & 外型 & 内蚛 & 外 1 & 内晾 \\
\hline & 960 & 1118 & 510 & 735 & 178 & 250 & 71 & 61 \\
\hline 90 以下 & $3.5 \%$ & $1.0 \%$ & $33 \%$ & $1.5 \%$ & $11 x$ & $0.4 x$ & $1.4 x$ & $0 \%$ \\
\hline $100-100$ & 1.10 & 0.6 & 9.1 & 6.0 & 2.8 & 3.2 & 20 & 3.3 \\
\hline $110-110$ & 23.5 & 20.8 & 17.5 & 15.8 & 140 & 10.0 & 5.6 & 0.2 \\
\hline $180 \sim 120$ & 26.5 & es.s & 202 & 20.5 & 16.0 & 13.5 & 160 & 60 \\
\hline $150-130$ & 16.1 & 10.4 & 17.3 & 10.5 & 230 & 20.6 & 14.1 & 10.0 \\
\hline $140 \sim 140$ & 0.3 & 110 & 11.0 & 113 & $1,1.2$ & 12.4 & 127 & 10.4 \\
\hline $150 \sim 150$ & 5.3 & 58 & 0.1 & 04 & 0.4 & {$\left[\begin{array}{llll}1 & 0 & 4\end{array}\right]$} & 127 & 140 \\
\hline $160-169$ & 20 & 2.8 & 4.8 & 6.0 & 7.3 & 6.6 & 0.5 & 4.0 \\
\hline $170 \sim 170$ & 1.0 & 2.2 & 1.0 & 4.8 & 79 & S.2 & 42 & 13.1 \\
\hline $100 \sim 180$ & 0.5 & 0.9 & 2.9 & 3.1 & 11 & 3.0 & 0 & 4.0 \\
\hline $100 \sim 100$ & 0.0 & 0.5 & 17 & 1.5 & 1.7 & 2.4 & 70 & 16 \\
\hline $200-200$ & 0.2 & 0.2 & 0.4 & 0.5 & 0 & 0.8 & 20 & 40 \\
\hline $210-210$ & Q.2 & 0.3 & 0.6 & 0.7 & 17 & 2.0 & 2.8 & 0 \\
\hline $220 \sim 220$ & 0.2 & 0.1 & 0.2 & 0.4 & 17 & 0.0 & 1.4 & 10 \\
\hline $230 \mathrm{WL}$ & 0.1 & 0 & 0 & 0.1 & 1.2 & 0 & 0 & 16 \\
\hline
\end{tabular}

表 2 , 男子警察官（40５9才）の作業別年令別血生 分布\%（驰期医）

\begin{tabular}{|c|c|c|c|c|c|c|c|c|}
\hline & \multicolumn{2}{|c|}{$40 \sim 44$} & \multicolumn{2}{|c|}{$45 \sim 40$} & \multicolumn{2}{|c|}{$50 \sim 54$} & \multicolumn{2}{|c|}{$53 \sim 50$} \\
\hline & 外数 & 夾数 & 外部 & 内少 & 外好 & 内散 & gk th & 散 \\
\hline & 980 & 1112 & 310 & 733 & 170 & 250 & 1 & 1 \\
\hline 40 以下 & $1 \%$ & $20 \%$ & $3 \times$ & $15 x$ & $22 x$ & $0 *$ & $42 \%$ & $16 x$ \\
\hline $50-$ & 10.2 & 7.1 & $\Delta$ & 3.5 & 3.0 & 6 & 0 & 0 \\
\hline $60-60$ & 273 & 22.3 & 20.6 & 163 & 140 & 0.2 & 155 & 0.0 \\
\hline $70-$ & 27.0 & 20.0 & 24.5 & 260 & 246 & 24.0 & 100 & 81.3 \\
\hline $00-00$ & 163 & 19.2 & 10.0 & 215 & 24.2 & 23.2 & 2111 & 23.0 \\
\hline $90 \sim 00$ & 10.1 & 12.0 & 18.8 & 162 & 174 & 226 & 107 & 23.0 \\
\hline 100 & 3.3 & 40 & 0.2 & 0.6 & 0.0 & 10.6 & 6.5 & 14.8 \\
\hline $110=$ & 1.5 & 2.1 & 3.1 & 41 & 2.2 & 44 & 4.2 & 3.3 \\
\hline $120-120$ & 1.0 & 0.5 & 1.2 & 1.5 & 2.2 & 2.0 & 2. & 3.3 \\
\hline 130 以上 & 0.3 & 0.3 & 0.2 & 10 & 0 & 16 & 0 & 0 \\
\hline
\end{tabular}


図 1. 男子警察官（40５9才）の作美別年令別血珐分布

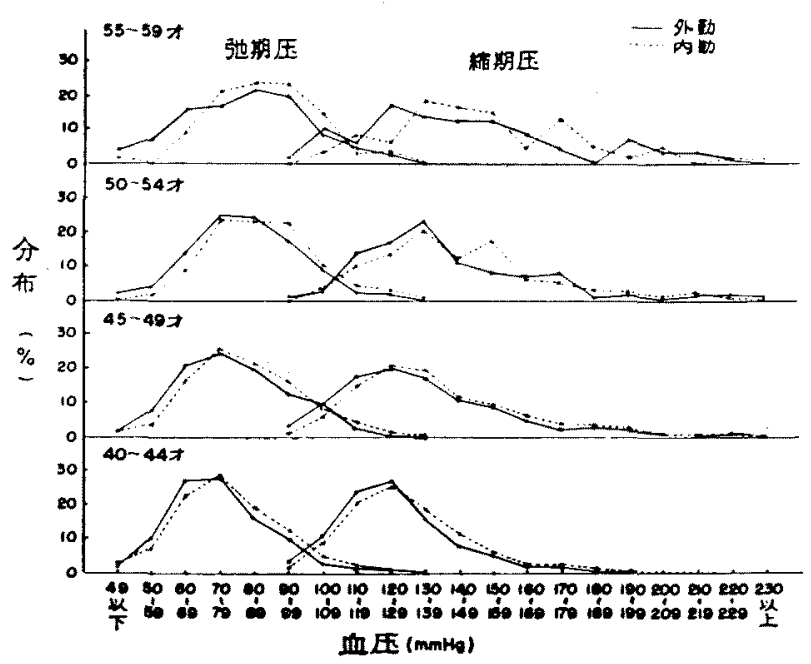

に比し内勤のカが少しづつ高血王則入移行してい る.

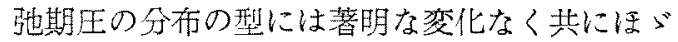
正規分布に近い型を示すが，縮期王と同様外勤に 比し内勒の方が少しつつ高血压側八移行してい る.

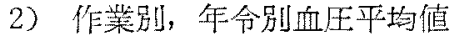

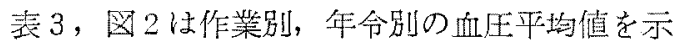
したものである。これは高血圧者索除か方被检者 全員について行なつたものである。緛期王，献期

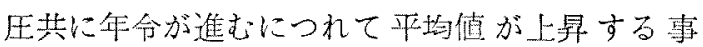

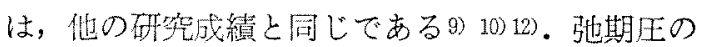

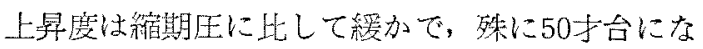
ると年令によつてまとんど昰化しない，作業の血

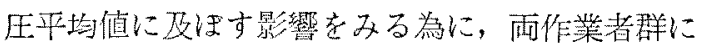

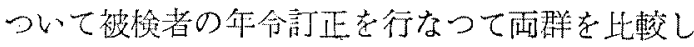
てみると, 維期生では外勤 $131.0 \mathrm{mmHg} \pm 22.9 \mathrm{mmHg}$,

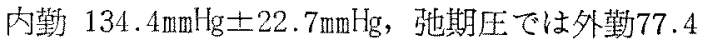
$\mathrm{mmHg} \pm 162 \mathrm{mmHg}$, 内勤 $82.1 \mathrm{mmHg} \pm 16.3 \mathrm{mmHg}$ であつ

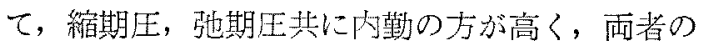
間には危险社 $1 \%$ 以下の有意の差がある.

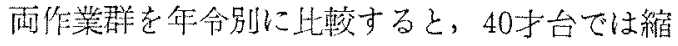

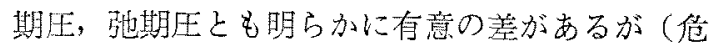

表 3. 男子警察官の作業別年令別血圧平均值

(頝期压 $\mathrm{mmHg}$ )

\begin{tabular}{|c|c|c|c|c|c|c|}
\hline \multirow{2}{*}{$\infty_{(\lambda)}^{n I}$} & \multicolumn{3}{|c|}{ 外 勤 } & \multicolumn{3}{|c|}{ 内 勤 } \\
\hline & $2 x$ & 血圧平坊值 & 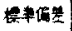 & 弡林者位 & 血压平均掼 & 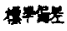 \\
\hline $40-44$ & 960 & 126.9 & 19.6 & 1112 & 129.7 & 10.1 \\
\hline $45-49$ & 519 & 1331 & 23.5 & 735 & 137.4 & 23.9 \\
\hline $50 \sim 54$ & $17 \theta$ & 142.4 & 27.2 & 250 & 145.0 & 24.7 \\
\hline $55 \sim 58$ & 71 & 145.9 & 30.4 & 61 & 152.5 & 28.9 \\
\hline $40 \sim 59$ & 1720 & 1312 & 22.9 & 2158 & 1347 & 22.7 \\
\hline 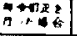 & & 131.0 & & & 134.4 & \\
\hline
\end{tabular}

(弛期压 $\mathrm{mmHo}$ )

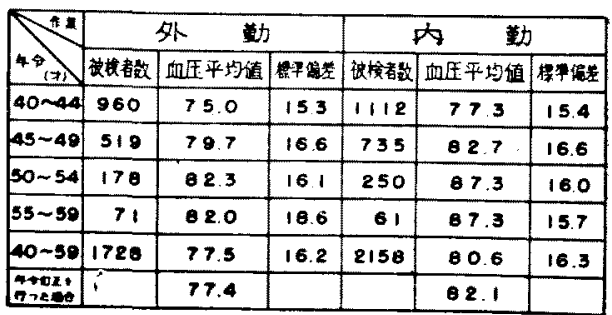

狯溹 $1 \%$ 以下)，50才台では弛期圧の50〜 54才にの み危除率 $1 \%$ 以下で有意の美がある。他は縮期 圧，施期圧とも傾问は認められるが統計学的有意 の差は無い。これは40才台に比して50才台の被検 者の数が少ない為と思われる。

3）作業別，年令别高血圧出現頻度 
図 2. 男子警察官 $(40 \sim 59$ 才) の作業別年令別 血王平均值

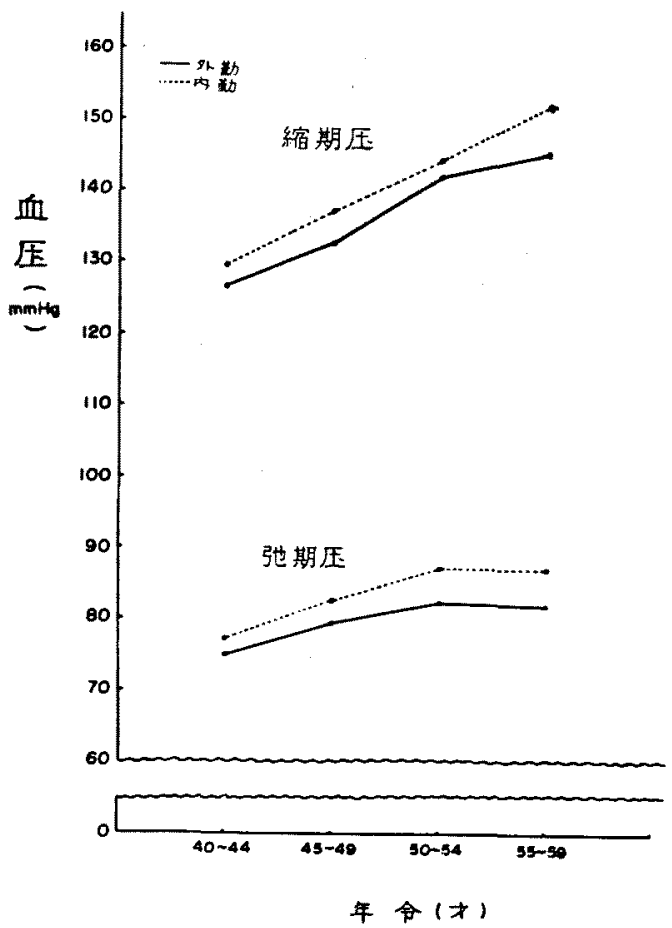

表 4. 男子警察官（40〜59才）における作菜別年令 別高血王出現頻度

緒期压 $150 \mathrm{mmHg}$ 以上㰻血压をする

\begin{tabular}{|c|c|c|c|c|}
\hline \multirow{2}{*}{$\int_{(\rightarrow)}$} & \multicolumn{2}{|c|}{ 外 彭 } & \multicolumn{2}{|c|}{ 内 晾 } \\
\hline & 被检者 & 高的压萻 $(\mathbf{x})$ & 神模者 & 离进在者( \\
\hline $40-44$ & 960 & 110 & 1112 & 12.8 \\
\hline $45-49$ & 510 & 21.6 & 735 & 26.1 \\
\hline $50 \sim 54$ & 178 & 30.9 & 250 & 306 \\
\hline $55-59$ & 71 & 30.4 & 61 & 47.5 \\
\hline $40 \sim 59$ & 1728 & 17.4 & 2150 & 21.4 \\
\hline 年A & & 17.2 & & 20.1 \\
\hline
\end{tabular}

驰期压 $90 \mathrm{mmHg}$ 以上を息血压 $\varepsilon す を$

\begin{tabular}{|c|c|c|c|c|}
\hline 81 & \multicolumn{2}{|c|}{ 外 勤 } & \multicolumn{2}{|c|}{ 内勏 } \\
\hline & 被挨者 & 息能压青 (x) & 被检者 & 高船庄者( \\
\hline $40 \sim 44$ & 960 & 16.3 & 1112 & 20.8 \\
\hline $45 \sim 49$ & 519 & 26.2 & 735 & 31.3 \\
\hline $50-54 \mid$ & 176 & 30.9 & 250 & 42.0 \\
\hline $55 \sim 59$ & 71 & 35.2 & 61 & 44.3 \\
\hline $40 \sim 59$ & $172 \theta$ & 21.5 & 2158 & 27.5 \\
\hline 年鸽正 & & 18.5 & & 26.9 \\
\hline
\end{tabular}

図 3、男子整察官 $(40 \sim 59$ 寸) に如ける作業別年令 別高血圧出現頻度
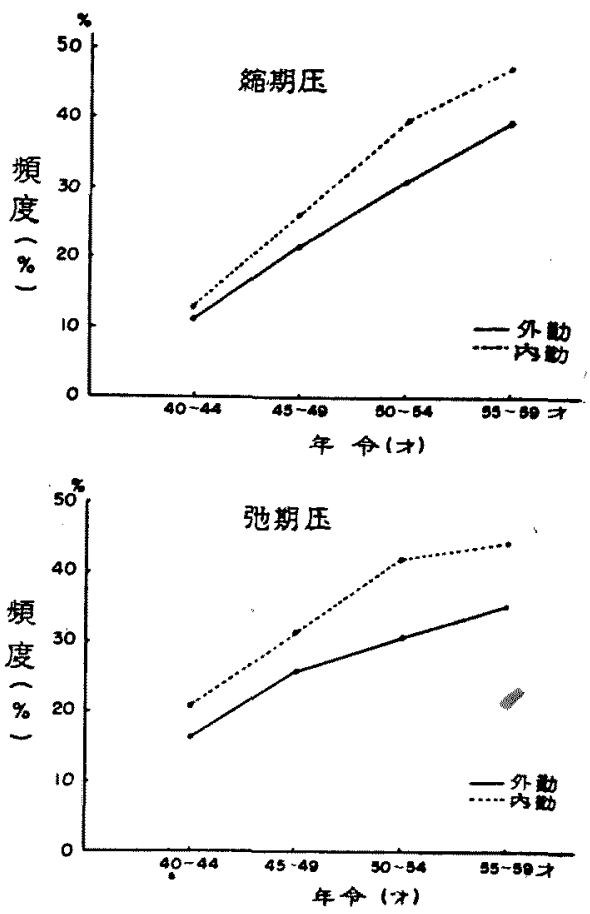

正常血圧と高血圧の限界をどこにおくかについ ては種々議論があり今日に至るも定説がないしし

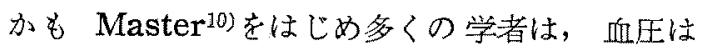
年令と共に上昇すると云う立場をとつているが， Alverez, Boynton ${ }^{11)}$, 金井12)等は, 正常血圧は 成人以後は年令による影䇺を受けず一定であると している。こっでは最も妥当な值と考えられる維 期压 $150 \mathrm{mmHg}$ ，弛期圧 $90 \mathrm{mmHg}$ を限界とし，これ以 上を高血纴者とした8)13)。

表 4, 図 3 は外勤々内勤の高血圧出現頻度を年 令別に示したものである. 縮期圧, 弛期圧共に年 令が進むに従つて出現頻度が增大するのは他の成 綪と同様である8).

作業別の比較を外勤と内勤についてそれぞれ年 命訂正したものについて差の有意性を检討する と, 樎期圧については内勤 $20.1 \%$ の方が外勤 17.2 \%よりも5\%以下の危険率で大であり, 弛期圧に つては内勤 $26.9 \%$ 万方外勤 $18.5 \%$ より $1 \%$ 
以下の危隃率で大である。さらに福田タの規潐に 従つて蚞討してみた。即ち45才〜54才の縮期圧 $150 \mathrm{~mm} \mathrm{Hg}$ 以上者は，外勤 697名中23.9\%，内勤 985名中 $29.5 \%$ で内勤に高く，出者の間には有意

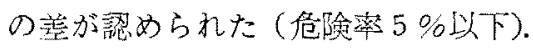

4) 高血圧者の臨床検查

集団佮診の結果臨床检查老必要とする者の中, 実際に来院した者は外勤 103名，内歎 129名であ つた．統計学的考察を加えるには人数が少ないの で，32年度，33年度に新たに来院した外勤81名， 内勤 149名を加えて観察した。

臨床㭲查の中こっでは特に眼底检查，原検查， 心電図桱查の三つをとりあげ，検督所見と労働条 件の関係を檢傠した。

\section{(i) 眼底所見}

高血厈症及び血管硬化症の病型，予後を決定す る上に，眼底所見は重要な因于の一つである。表 5 は外勤 184名, 内勤 278名の眼底所見を KeithWagener ${ }^{14)}$ の分類に従つて分類したものである. Keith-Wagener II 度以上を有所見者とすると，

表 5. 来院高血王者の作篻別年令別眼底所見 (Keith-Wagener の分類)

外勤

\begin{tabular}{|c|c|c|c|c|c|c|c|c|c|c|c|}
\hline$\rightarrow m$ & IF & 㗬 & & $N I$ & & $N$ & & I I & & $\pi$ & 㖕 \\
\hline & $a_{0}$ & $\%$ & Fin & $x$ & 83 & $x$ & $4_{4}$ & $\%$ & ming & $\%$ & \\
\hline $40-44$ & 9 & 15.0 & 35 & 58.3 & $\theta$ & 13.3 & 0 & 13.3 & 10 & & 60 \\
\hline $45-48$ & 3 & 4.5 & 39 & 59.1 & 18 & 27.3 & 6 & 91 & 0 & & 66 \\
\hline $50-54$ & 3 & 7.1 & 24 & 57. & 11 & 26.2 & 4 & 9.5 & 0 & & 42 \\
\hline $55-50$ & 1 & 6.3 & 5 & 313 & 10 & 62.5 & 0 & 0 & 0 & & 16 \\
\hline 計 & 16 & 8.7 & 103 & 560 & 47 & 25.5 & 18 & 9.8 & 0 & & 184 \\
\hline & & 11916 & 4.78 & & & & & 181 & $98 x$ & & \\
\hline & & & & & & 651 & 35.3 & $x \rightarrow 7$ & 0133 & $\theta x$ & \\
\hline
\end{tabular}

丙㔟

\begin{tabular}{|c|c|c|c|c|c|c|c|c|c|c|c|}
\hline & II & 掌 & & $N I$ & & II & & w m & & & it \\
\hline & 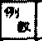 & $x$ & 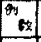 & $x$ & 8 & $x$ & (3) & $x$ & 都 & $x$ & \\
\hline $40-44$ & 8 & 90 & 52 & 58.4 & 23 & 25.8 & 5 & 5.6 & 1 & 1.1 & 89 \\
\hline $45-49$ & 2 & 16 & 65 & 52.4 & 45 & 36.3 & 12 & 9.7 & 0 & & 124 \\
\hline $50-54$ & 3 & 57 & 22 & 42.3 & 19 & 36.5 & 0 & 15.4 & 0 & & 52 \\
\hline $55-50$ & 10 & & 4 & 30.8 & 6 & 46.2 & 3 & 23.1 & 0 & & 13 \\
\hline st & 13 & 4.7 & 143 & 51.4 & 83 & 33.5 & 20 & 10.0 & 1 & 0.4 & 278 \\
\hline & & 156 & (56.) & & & & & 29 & 4 & & \\
\hline & & & & & & 12216 & 43.8 & $x \neq 0$ & and & $39 x_{1}$ & \\
\hline
\end{tabular}

年令訂正有所見者率は外勤 $34.8 \%$ ，内勤 $43.9 \%$ と なり，両者の間には俈険梓 5\%以下で有意の差が ある。

表 6 . 来院高血圧者の作篻別年命別尿所見

外 勤

\begin{tabular}{|c|c|c|c|c|c|c|c|c|c|}
\hline 9 & 正 & 常 & & 与性 & & 阵 & & 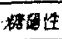 & 部 \\
\hline 过 & 96 & $x$ & 两 & $x_{0}$ & 制 & $\%$ & 陪 & $\%$ & \\
\hline $40-44$ & 55 & 31.7 & 4 & 6.7 & 1 & 17 & 0 & & 60 \\
\hline $45 \sim 49$ & 53 & 80.3 & 10 & 15.2 & 2 & 3.0 & 1 & 1.5 & 66 \\
\hline $50 \sim 54$ & 32 & 76.2 & $\theta$ & 190 & 2 & 4.8 & 0 & & 42 \\
\hline $55 \sim 59$ & 13 & 01.2 & 2 & 12.5 & 1 & 6.3 & 0 & & 16 \\
\hline 計 & $\mid 153$ & 832 & 24 & 130 & 6 & 3.3 & 1 & 0.5 & 184 \\
\hline & & & & 31116 & 9 & 会酊 & 16.6 & & \\
\hline
\end{tabular}

\section{内 勤}

\begin{tabular}{|c|c|c|c|c|c|c|c|c|c|}
\hline \multirow{2}{*}{ and } & \multirow{2}{*}{\begin{tabular}{|l|} 
正 \\
Ast
\end{tabular}} & \multirow{2}{*}{$\frac{\text { 常 }}{x}$} & \multicolumn{2}{|c|}{ 蛋百腰性 } & \multicolumn{2}{|c|}{ 售陆性 } & \multicolumn{2}{|c|}{ 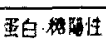 } & \multirow[t]{2}{*}{ 計 } \\
\hline & & & of & $x$ & sin & $\%$ & 列 & * & \\
\hline $40-44$ & 72 & 80.9 & 14 & 15.7 & 2 & 2.2 & 1 & 1.1 & 09 \\
\hline $45 \sim 40$ & 80 & 718 & 25 & 20.2 & 9 & 7.3 & $\sqrt{1}$ & 0.8 & 124 \\
\hline $50-54$ & 38 & 73.1 & 7 & 13.5 & 6 & 11.5 & 1 & 1.9 & 52 \\
\hline $55 \sim 50$ & 10 & 76.9 & 3 & 23.1 & 0 & & 0 & & 13 \\
\hline Et & 200 & 74.8 & 49 & 17.6 & 17 & 61 & 3 & 12 & 278 \\
\hline & & & & 812 & 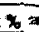 & 0 & & & \\
\hline
\end{tabular}

表 7 . 来院高血王者の作業別年令別心電図所見

\section{外勤}

\begin{tabular}{|c|c|c|c|c|c|c|c|c|c|c|c|c|c|}
\hline \multirow{2}{*}{$\Rightarrow \sum_{i \rightarrow 1}$} & \multirow{2}{*}{ 正 } & & \multicolumn{2}{|c|}{ 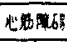 } & \multicolumn{2}{|c|}{ 比肥大 } & \multicolumn{2}{|c|}{ 15rof } & \multicolumn{2}{|c|}{ 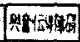 } & \multicolumn{2}{|c|}{ 其他 } & \multirow[t]{2}{*}{ 計 } \\
\hline & & & |ats & $x$ & ma & $\%$ & 双 & $x$ & sin & $x$ & 89 & $x$ & \\
\hline $40-44$ & 48 & 800 & 4 & 6.7 & 4 & 6.9 & 2 & 3.3 & 1 & 1.7 & 1 & 17 & 60 \\
\hline$-4 \theta$ & 53 & 70.0 & 6 & 27 & 5 & 7.2 & 2 & 2.9 & 1 & 1.4 & 2 & 2.9 & 69 \\
\hline $50-54$ & 35 & ras & 6 & 13.6 & 2 & 4.5 & 0 & & 0 & & 1 & 23 & 44 \\
\hline $55-59$ & 10 & 580 & 1 & 5.9 & 3 & 176 & 2 & 11.8 & 0 & & 1 & 5.9 & 17 \\
\hline 計 & 1940 & $\theta$ & 17 & 0.9 & 14 & 7.4 & 6 & 32 & 2 & 1.1 & 5 & 2.6 & 190 \\
\hline & & & & $4\{2$ & & & 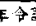 & 正 2 & 2.8 & & & & \\
\hline
\end{tabular}

\section{内 勒}

\begin{tabular}{|c|c|c|c|c|c|c|c|c|c|c|c|}
\hline 58 & 掌 & (c) & & 必肥 & & 618 & & sin & 国 & 他 & 塾 \\
\hline & 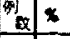 & & $\times$ & a) & $x$ & & & ax & 6 & $x$ & \\
\hline & 00000 & & 1.1 & 4. & 4.5 & & 1 & & 2 & 1.1 & 89 \\
\hline $43 \sim 40$ & 100403. & 5 & 4.0 & 75 & \begin{tabular}{l|l|l|}
5.6 \\
\end{tabular} & & 8 & & 8 & 1.6 & 125 \\
\hline $50 \sim 56$ & 42000 & 3 & 5.8 & 35 & 58 & & 8 & & 9 & 18 & 52 \\
\hline $50-50$ & 11000 & 60 & & 17 & 7 & & & & 70 & & 13 \\
\hline 計 & $237 \mathrm{pecs}$ & 9.1 & 3.2 & & 24 & & 12 & & & 1.4 & 279 \\
\hline & & & & 15.1 & $x$ & & 正 & 4.9 & & & \\
\hline
\end{tabular}

（注）異常所見が二つ以上ある時は，それでれ別に して分類した。 
(ii) 尿所茪

尿所見としては蛋圭(スルフォサルチル酸試験) と，糖（ニーランデル試験）の定性检查を行なつ た。結果は表 6 の通りである，蛋白陽性，糖陽性 及び蛋白・糖陽性の何れも有所見者とした，年令 訂正有所見者率は外勤 184 名中16.6\%，内勤 278 名中 $24.2 \%$ で内勤に高く，両者の間には危険率 5 \%以下で有意の差が認められた。

(iii) 心電艮所見

直記式心電計を用い仰卧位で12誘導の描記を行 なつた.外勤と内勤を比較すると表 7 の如くで, 心 電図上異常所見を呈する者は（型の变化は異常所 見に入れない）年令訂正を行なうと外勤 $22.9 \%$ ， 内鋥 $14.9 \%$ で前記の眼底所見，尿所見にくらべ心 電涩検查で舛外勤の方に異常所見を呈する者が多 く，両者の間には危険摔 $5 \%$ 以下で有意の差が認 方られ。、文勤に比し外勤には心筇障害，心肥 大等心箦に異常を示す所見の者が多かつた。

\section{IV 総括及び考案}

我国における労働と高血圧とに関する先人の報

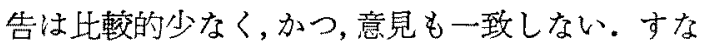
わ方曾山3）梳鉣の従業員の血王検診の結果を坑 外夫と坑内夫に分けて比較検討している方，血圧 平均值，高血圧出現頻度のいずれについてむ両者 の間に差がみられなかたと報告している。同様に 操4，日吉，金井12)等も職業或は職種と血圧の間 には関係がないとしている，一方，職業或は職種 と血圧の間には関係があるという報告もある。高 橋らによれば八幡製鉄所従業員（40才以上の男 子）検診の結果として，作業強度別縮期纴平均值 は労㗢強度の大である程血生水準はむしろ低くな つており，軽作業者に最も高い値を示したとい う. 鈴木15) は德島県下郵便局職員の血圧調查で縮 期任，弛期圧共に外勤者に比し内勒者に高く，堌 田16) 㥩京都交通局従業員の血圧調查で机上事務 者に高血生百分率が最も高かつたとしている。し 亦し小松1门は林業徒事者, 表夫, 化学学務者, 郵 政従業員等の血圧を比較し，農夫，樵夫が高く次 いで郵便局員，化学工場学務者加最も低加つたと 云つている。このように労衝と高血圧との関係は
人によつて意見が区々である。そこでこの点につ いて警視庁の満40才方満59才迄の警察官を対象 として検討してみたのである。

1）血压平均値

縮期圧平均值は年令と共に上䒜し，外勤 126.9 〜 145.9mm Hg, 内勤 $129.7 \sim 152.5 \mathrm{mmHg}$ 範围定 変動し，外勤に比し内勤に高く，耐者の聞には有

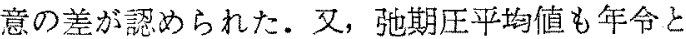
共に上昇し，外勤75.0 $82.0 \mathrm{~mm} H \mathrm{gg}$ ，内勤77.3 $87.3 \mathrm{mmHg}$ で外勤に比し内勤に有意に高い。これは 高橋5)による八幡製鉄従業員の成續に一致し，又 鈴木15)，增田16)の成績とも一致する。

一方, 筋肉学衝の激しい患村, 殊に東北地厅の 農村で注血厈平均值が極めて高い58)．しかし農 村の高血仕は単に労㗢量㚙大であるばかりでな

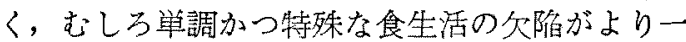
層大きな影響を与えており 18 ，農村と都会の血王 を比較する時，労衝量の大小のみをもつて考える 事は不適当である。一般の労㗢者では労働量が相 当に大である場合でも，適切な学働時間が守られ る場合には，血死水準の上昇には大きな影響を与 えず，むしろ他の因子，すなわち精神的ストレス がより一層血圧上昇の因子と成つているのではな いかと考光られる19)。

2）高血圧者出現率

縮期圧 $150 \mathrm{mmHg}$, 弛期王 $90 \mathrm{~mm} H \mathrm{Hg}$ 限界として, これ以上を高血圧者として，外勤と内勤の2 群を 比較した。この場合, 両群の年令を訂正して高血圧 者出現率算出すると，縮期圧については内勤で は20.1\%であつて，外勤の $17.2 \%$ よも有意に高 かつた。また，弛期圧については内勤では26.9\% であつて外勤の $18.5 \%$ よも有意に高かつた。さ らに福田8)の規潗に従つて職種別に比較すると， 45〜54才の縮期圧 $150 \mathrm{~mm} H \mathrm{~g}$ 以上の者は外勤 23.9 $\%$, 内勤29.5\%示し, 内勤に高く, 両者の間に は有意の差が認められた。しかし外勤，内勤何れ においても，福田8)の千葉県下の国鉄従業員の16 $\%$ ，一般工場従業員の18\%，県庁勤務者の15\%よ りも高く, 豊村の $41 \%$ 上は低い. 又今井6)の夕 
クシー運転手の58\%よりも低い. 何れにしても高 血王出現率はかなり䯩京である慗がわかる。

労働の比較的強い外勤に低く，内勤に高率であ る点について考えてみると, 肉体労㗢の激しい農 村の高発生率々一見矛盾しているょうであるが， 農村の高発生泇は血生平均值のところでも述べた 如く, 学働と共にその食生活が重要な因子となつ ている点を考虑しなければならない，同じような 激しい肉体労働に従事している漁民に高血圧発生 率が低い点からも，食生活が極めて重要な因子と なつている事がうなずかれる18).

以上の点加ら都会の同じような生活水準の警察 、官という一つの集団で, 肉体労働の比較的強い外 勤よりも，闪体労働の鸡い空内勤務に彷事する内 勤に, 高血生発生乷が有意に高いことは, 精神的贀 張を佯ないやすい室内の勤弱条件が，高血王発生 により強い影響を与え，学働規集法に規定する範 井内の肉体学働条件は，高血圧の発生にはあまり 影響がないと考えざるを得ない。これは福田7)の 報告と一致する. 又, 今井6）の労㗢基隻法の守方 れ難い都会労衝者の中，特に精神的ストレスを絶 えず受けているタクシ一運転手に，高血圧出現摔 が非常に高いことは、これを寒書きしていると考 えられる。

3）高血圧者臨床檢亘所見

( i ) 眼底所昌

眼底所胃は高血圧症の予後を判定する上に重要 な因子の一つであるが，Keith-Wagener II 度以 上を有所見者とすると，外勤 $34.8 \% ， 内$ 勤 $43.9 \%$

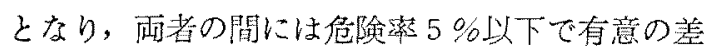
が認められる。新井等20は集団別，職業別に眼底 異常所見出現率を比較榆討し，肉体学衝者と知能 労働者の間にはほとんど差がないが，たぐ東京電 気通信局の肉体学働者上知能学働者の間にのみ有 意の差が認められ，夾休労働者の方に高率であつ たと報告している，労㗢と眼底所見の関係は明ら かでないが，警察官では高血圧発生率の高い内勤 に，眼底異常所見者も多かつた点恃注目すべきで ある。 (ii) 尿所兄

腎機能障害の有無は，高血圧の予後を決定する 上に重要な因子の一つである。こ〉では尿蛋白と 尿糖検查のみで, 詳しい腎機能検查を行なうこと は出来なかつたが，眼底所見と同様外個に比し， 内勤に異常所見者名有意に高く認められた。これ は労働条件が高血圧の発生に影響を与えるのみで なく，高血圧症そのものにも関係があるのではな いかと考えられる。しかし尿所見が高血圧症の発 生に一次的な関係があるかどうかは，なお一層詳 しい検查を行なわなければ決定出来ない。

\section{(iii）心電図検查}

心電図检查では眼底所見，死所胃と反対に高血 圧発生涥の低い外勤に異常所晃を呈する者が多 い. 福田2)は千葉々秋田の両県の国鉄從業員を調 查した結果, 高血王発生頻度は18\%文 $40 \%$ と著し い差があつたが，心電図上高血圧性心変化たる左 肥大型発生頻度は 4\%対 $5 \%$ で，ほとんど差がみ られなかつた。同様の関係が農村においてもみら れ, 高血圧性心電図変化の出現に関しては高血圧 発生とは別な因子が働くのではないかとしてい る. 警察官に扔いても心電図の異常所見出現率と 宫血圧発生家は平行せず，加えつて外勤に多い。 これは精神的掔張よりも肉体的労働による単純な 心葴負荷增大が，心電図異常所見発生の大きな因 子となつているのではないかと考えられるが，本 研究の被桱者である鳘察官の職铟選定の際に, 健 康管理的意見の入り方が足りなかつたという事も 考えられ，今後充分に検討すべき点と考えられ る.

\section{$\mathbf{V}$ 結 論}

警視庁の渾40才以上の職員約 5,000 名に循環器 柔集団検診を行ないこの資料の中から 40 才〜 59 寸の男子警察官 5,534名を選び，さらに作業別比 較の為に肉体労働の比較的激しい外勤 1,728 名 と，室内で勤務する事秝系の者 2,158名を内勤と して選び，両者の比較検討を行なつた。

血王平均值及び高血圧出現頻度は共に内勤に有 意に高かつた。この事から一見激務と思われる肉 
体労働も, 労働規準法内のものであるならば, 高 血圧の発生には余り影響なく，むしろ精神的緊張 を伴ないやすい室内の勤務条件の方が，強い影響 を与えるものと考えられる。

以上の労働条件は高血圧症の䙮床検查所見々も 関係があり，眼底所見，尿所見は内勤の力に異常 所見発現率方高く，心電园所見は外勤の方に異常 所見発現率が高かつた。

$$
\text { 文献 }
$$

1）吉田央：公衛生，23，115，1959。－2）福 田篤郎：日本の医学の1959年, IV, 535, 1959. 3）篔山幸夫：公采衙生， $23 ， 225,1959 .-4)$ 操 坦道：日本偱環器学誌, $19,227,1955$, 一 5 ) 高 橋英次：公衆衛生， $23,146,1959$. 一6) 今井力:
医学上生物学, 41, 163, 1956. 42, 127, 1957. $44,222,1957 .-7)$ 福田篤郎：臨床と研究, 37, $111,1960 .-8)$ 福田籍郎：公采衛生， 23，138, 1959，－9）渡辺定：総合臨牀，3，1447，1954. 10) Master, A.M.: J.A.M.A. 143, 1464, 1950. - 11) Boynton, R.E.: Arch. Int. Med. 80 454, 1945. - 12) 金井洯：保唤医学䧴誌，53，1, 1955. ー13）佐々貫之：医学シンポジゥム第 5 輯 高血 压, 141, 1957. - 14) Keith, N.M., Wagener, H.R. \& Barker, N.W.: Am. J. Med. Sei., 197, $333 ， 1939$. - 15) 鈴木幸夫：日本衛生学雑誌, 13 , $60,1958 .-16)$ 增田浄: 日本医大雑誌, 25,495 , 1958. - 17) 小松富三男: 日本衛生学雑誌, 13, 9 , 1958. - 18）中沢房吉：医学シンポジム第 5 輯 高血圧, 82, 1957. - 19) Mills, L.C.: Am. J. of Cardiology, IV, 711, 1959, - 20) 新井宏咄 他：公采衛生, 24, 108, 1960 。 